\title{
LEVE I BYEN ELLER MED BYEN BY OG LITTERATUR EFTER MODERNISMEN
}

\section{En litteraturhistorisk fordrejning}

Det hører til den litteraturhistoriske børnelærdom at by og modernitet hænger sammen som siamesiske tvillinger. Det er heller ikke forkert. Men det litteraturhistoriske paradigme der også hører til denne børnelærdom, absoluterer den by vi møder i al dens mangfoldighed i den modernistiske litteratur, så den skygger for forestillingen om en anden by hinsides denne horisont, både bagud og fremad i historien, en sådan bys mulige rolle i litteraturen og de begreber der kan indkredse denne rolle. Jeg påstår ikke jeg løser dette problem, men jeg prøver at formulere det så man i det mindste kan få øje på den litteraturhistoriske fordrejning og begynde at arbejde sig ud af den.

Det er ubestrideligt korrekt at i byen finder modernitetens kulturelle, æstetiske og sociale processer deres koncentrerede og prototypiske udtryk, og moderniteten er selv en proces der drives fremad af den urbane kultur - byer breder sig med modernitetens produktions- og livsformer over hele verden, og modernitetens universaliserende ambitioner formidles gennem urbanitetens livsformer. Den litterære modernisme og andre æstetiske udtryksformer har denne gensidighed som sit motiv og sin drivkraft.

I Begreberne "modernitet", "modernisme" og "modernisering” bruges lidt blandet på tværs af litterære og æstetiske, sociologiske og kulturhistoriske kontekster. I denne artikel henviser "modernitet" til en historisk periode med udgangspunkt i europæisk historie fra ca. 1750 til i dag med globale konsekvenser og byggende på grundtræk som kapitalisme, sekularisering, borgerlige rettigheder, universelle menneskerettigheder, demokratiseringer, selvkritiske institutioner og andre træk kendt bredt fra modernitetsteori.

"Modernisering" er den proces hvor moderniteten udvikler sig og præger samfund og kultur i varierende, konkrete formationer. Nogle kalder disse differentierede former for forskellige "modernismer". Andre - og det gælder her - forstår ved "modernisme" en række litterære og kunstneriske strømninger der opstår i moderniteten, men også de er så forskellige i deres globale gennemslag at man har brugt udtrykket "modernismer" for at fremhæve differentieringerne.

Adjektivet "moderne" bruges enten til at karakterisere fænomener, litterære, æstetiske og andre, knyttet til moderniteten, eller mere neutralt og i overensstemmelse med etymologien (af middelalderlatin "modo") til at betegne fænomener med tilknytning til den til enhver tid gældende samtid i modsætning til fortiden. Her optræder adjektivet kun én gang i den sidste betydning. 
Overalt støder byen mod lokale kulturformer af anden art, og i mødet differentieres den europæiske modernisme i forskellige modernismer, med forskellige forudsætninger og manifestationer. Men byen er med hele vejen og samler modernismens mange facetter som ét komplet og komplekst portræt af byen - heterogent, kaotisk, diskontinuert på den ene side, som en futuristisk skulptur, og strømlinjet, homogeniserende på den anden, formidlet gennem de ofte usynlige og translokale infrastrukturer der holder byens flimrende overflade sammen, som et maleri af Vasarely. I byen marcherer alle taktfast i hver sin retning. Sådan har byen været skildret i litteraturen helt tilbage til antikkens Rom, især i Juvenals 4. satire, men kun som et moment af byen, ikke som et konstituerende træk som i det I9. og det tidlige 20. århundredes by.

Modernismens by er derfor både elsket og hadet, aldrig neutral. Sådan blev byen også fremstillet før modernismen. Men her elskes og hades den på en bestemt måde fordi byen ikke er et sted man bare kan forlade eller holde sig væk fra. Den giver mennesker en uendelighed af valg, undtagen ét: Man kan ikke vælge byen fra. Den er over det hele, og er den der ikke i fysisk form, så forlænger dens strukturelle virkninger sig hinsides byens labile fysiske grænser ind i vores privatliv, bevidsthed, økonomi, naturoplevelse, ja i hele vores grundlæggende strukturering af tid, rum og subjektivitet. Det er byens allestedsnærvær som provokerende magt der direkte og indirekte er modernismens drivkraft og tema for den modernistiske beskæftigelse med byen i litteratur og kunst.

Men byen er der ikke bare over det hele som den blå himmel over litteraturens landskaber. Den gør noget overalt, som et subjekt hinsides menneskelige dimensioner der sætter forskelle mellem dig og mig, os og dem, godt og ondt, bevidst og ubevidst, orden og kaos, kultur og natur - en uendelig række af urbant determinerede dikotomier. Selv det ikke-urbane rum som naturen urbaniseres uundgåeligt som dikotomi når den gribes af den urbaniserede modernismes litterære og andre udtryksformer: vild og tæmmet natur, resourse og affald, produktionsnatur og fritidsnatur.

Denne byopfattelse, eller måske snarere lidt bredere og mere ubestemt: byerfaring, dukker stedvis op i I70o-tallets europæiske litteratur og begynder at orkestrere tvetydigheden i vores opfattelse af menneskets evne til at skabe et livsrum efter sit eget hoved (Johnston). Her tager den form af en dyrkelse af det kosmopolitiske, knyttet til de endnu få storbyer eller urbane wannabe-lokaliteter. En urbanerfaring for de få der både kan rejse til og fra byen - helst bestemte byer som London, Rom og Paris - og som samtidig reflekteret kan omsætte oplevelsen til fremstilling af urbanerfaringen som en ny generaliseret kulturerfaring. Det første tværurbane tidsskrift som London und Paris (I798-I8I5) (fra I8II udvidet med Wien) udtrykker denne tendens.

Fascinationen og tvetydigheden griber om sig i romantikken, hvor oplevelsen af byen, ikke bare som et privilegeret sted, men også som et sted man ikke rigtig kan slippe væk fra, f.eks. i William Wordsworths selvbiografiske digt The Prelude 
(I805, publ. I850) eller E.T.A. Hoffmanns prosa (Larsen, "Fra kvalmfulde Mure"). Med de store realistiske byskildringer hos Honoré de Balzac og Charles Dickens er byen både et sted og en aktiv handlingsbærende kraft i langt de fleste af deres romaner, total i sin inkludering af næsten alle menneskelivets sider og derfor så mystisk, forunderlig og stærk som naturen selv - et sted for eventyr, eksotik og hverdagens konflikter og en formende kraft bag menneskelig mentalitet og motivstrukturer i talrige symbolske gevandter (Larsen, I byen med Balzac).

Herfra går den lige vej ind i den ekspanderende modernistiske litteratur i og uden for Europa, fra Ural i øst og videre over Atlanten til USA i vest - Nicolaj Gogol, Fjodor Dostojevskij, Charles Baudelaire, Emile Zola, James Joyce, Walt Whitman, Edgar Allan Poe, Henry James i en fortsat uendelig række. Selvom de er så forskellige som tænkes kan, har deres værker byen som en fælles klangbund, og viser dermed at den i sig selv er så omfattende og gennemgribende at fortolkningerne og den æstetiske brug af den ikke ensretter, men differentieres i nye genrer som krimi og kortprosa, nye virkemidler i kollager, fortælleformer og billedsproglige eksperimenter og nye medier som film og radio. Ligesom byudviklingen selv når den forskellige steder på kloden i moderniteten antager lokale former der nok er forskellige, men også sammenlignelige som del af samme moderniseringsbevægelse.

Først i slutningen af det I9. århundrede suppleres denne æstetiske udforskning af den dynamiske samtidsby som grundlæggende kulturformation med sit filosofiske, teoretiske og videnskabelige metaniveau der prøver at sætte erfaringen på begreb. Det sker i kølvandet på den gryende sociologi med de samme blandede modernistiske og kulturkonservative positioneringer som i litteraturen i de foregående I50 år, primært hos Georg Simmel og Max Weber omkring århundredskiftet og senere i USA hos Chicagoskolens folk som Robert Park og Louis Wirth eller alternativt hos Lewis Mumford, alt sammen som reaktion på urbaniseringseksplosionen der for første gang gjorde det forudsigeligt at flere mennesker blev byboere end landboere.

I litterær sammenhæn blev især Simmels essay "Die Großstädte und das Geistesleben” (1903) toneangivende i den interesse for studiet af forholdet mellem by og litteratur der tog fart i I960'ernes internationale litteraturforskning. Den samlede også mellemkrigstidens bykulturelle koryfæer op, primært Walter Benjamin, hvis værker netop blev udgivet i samme periode, men også Siegfried Krakauer. Hvad jeg har skrevet ovenfor er stort set et koncentrat af de kilometervis af bøger og artikler der er udkommet siden da, på dette teoretiske inspirationsgrundlag.

Man kan som sagt ikke sige det er forkert, slet ikke. Og det var nybrydende for litteraturforskningen i I960'erne så den blev historisk igen på trods af nykritikkens autonomidyrkelse, og blev historisk på en anden måde end den traditionelle filologiske historisme med positivistiske træk og den nationalt orienterede isolation af litteratur i lokale enklaver. Fint nok og uundværligt. Men mere fundamentalt 
begynder med dette litterært-kulturelle urbane paradigme en litteraturhistorisk fordrejning af modernismen der skygger for den meget bredere og mere nuancerede forståelse af bykulturen der udviklede sig i de litterære værker og også andre udtryksformer fra I700-tallet og frem.

Denne fordrejning giver nogle begrænsninger i studiet af by og litteratur der kan samles i fire punkter jeg stiller op om lidt. Under ét betyder de at det bliver vanskeligt, måske umuligt, fra den modernistiske byerfaring både at forstå hvordan den by der følger efter den klassiske modernisme ser ud og bliver oplevet, og at forstå den lange byhistorie der ligger før modernismens by, så man kan se at den også er historie for andet og mere end denne by. Den universaliserende tendens i modernismen og i moderniseringsprocesserne generelt gælder også det bykoncept der styrer litteraturforskningen - byudviklingen fra før ca. 1750 fører frem til netop den slags by modernismen sætter ord og billeder på, og på den anden side af den er ikke andre byforestillinger og byforståelser mulige. Denne dobbeltorientering er nødvendig hvis nytænkning skal betyde noget.

\section{Andre muligheder?}

Det er hårde ord, også fordi jeg selv har deltaget aktivt i den forskningsudvikling jeg har opsummeret, om end også med alternative indfaldsvinkler nu og da (se litteraturlisten), og fordi jeg ikke har en færdig plan for et alternativ, kun en lokalisering af et behov ud fra kritikken nedenfor i fire punkter og en antydning af hvor man kan lede efter en ny knage at hænge sin urban-litterære hat på.

I) Enkeltbyer: Udgangspunktet er den individuelle by, med udvalgte byer som prototypiske for denne individuelle særegenhed, hvor især Paris har fungeret som modelby. Det er trækkene i dens udvikling - i kulturliv, byplanlægning, æstetik, økonomi, sociologi, kommunikation, psykologi, institutionsformationer osv. som har udgjort et generaliserende bagtæppe for refleksionen over by overhovedet. Mange redegørelser har derfor talt om Byen i et kategorialt ental og med stort B med Paris som model for mange varianter. Ikke forkert: Paris blev jo kopieret rundt omkring i verden. Derfor kan man lave byportrætter, næsten som personportrætter: Paris i litteraturen, London, Wien, Berlin, København, New York, Chicago i litteraturen osv. Den grundlæggende diskussion er at byen ændrer den opfattelse af sted som har hersket siden europæisk oldtid - den er ekspansiv, den er dynamisk, den opleves som uoverskuelig, den distancerer mennesker fra naturen, den ødelægger identitetsdannelser osv. Negative kategorier som ikke-sted, stedløshed, ikke-natur o.l. bærer karakteristikken når byen går over sine bredder og centrum hele tiden flytter sig eller helt forsvinder.

2) Bagudskuende udgangspunkt: Baggrunden for denne karakteristik ligger allerede hos Simmel i den nævnte skelsættende artikel fra 1903 der giver en præcis karakte- 
ristik af det I9. århundredes ekspansive by som et nyt kultur- og oplevelsesrum. Men af meget forståelige grunde er baggrunden for hans beskrivelser ikke den by han ser for sig, men den der bliver ændret - typisk den europæiske middelalderby af afgrænset og begrænset størrelse. Forståeligt når man møder nye fænomener man endnu ikke har klare begreber om på alle de niveauer hvor de skal begribes. Så må man tage afsæt i det man kender, og danne generative metaforer der bringer forståelsen på vej. Sådan har det været med nye naturerkendelser (el set som strøm) og med den digitale revolution (digitale processer set som net). Jeg har derfor heller ikke kaldt ham nostalgisk (modsat f.eks. Lewis Mumfords antimoderne The City in History (196I)). Men det bagudskuende udgangspunkt bliver en begrænsning, hvis det ikke fores videre når erkendelsen af fænomenet flytter sig. Denne begrænsning viser sig både i forhold til en byudvikling der går ud over det modernistiske udgangspunkt, og også i forhold til den byhistorie der så at sige låses fast baglæns ved at få tildelt netop denne bytype som endestation.

3) Centraleuropaisk perspektiv: I denne optik er den generaliserede by forst og fremmest den centraleuropæiske by og dens historie tilbage til bystaterne og de typiske middelalderbyer med torve, volde og centrum tilbage til antikken, en historie der i stort omfang også bruges som forståelsesmodel for byer andre steder i verden. Og ganske vist holder vi alle af piazzaerne, men de giver næppe en dækkende forståelse for at den globaliserende tendens i byudviklingen også har andre forudsætninger. De tre toneangivende foregangsmænd hvis ideer og begreber overføres til det litteraturhistoriske studium af by/litteratur-forholdet, Simmel, Weber og Benjamin, har trods deres betydning intet blik for de selvstændige tendenser der ligger i USA's byudvikling eller i de koloniale byer rundt om i verden (Larsen, I byen med Balzac; kap. 3). Det er en generaliserende byforståelse med en stærkt begrænset historisk platform som basis for den generaliserende ambition der bærer den, og for byens faktiske globaliserede realitet. Selv en bog som Dana Brands udmærkede The Spectator and the City in Nineteenth Century American Literature (I99I) handler mest om den europæiske flanør i litteraturen som baggrund for at forstå amerikansk litteratur. Den almene byhistorie er fremstillet $\mathrm{i}$ andre historiske og teoretiske redegørelser betydeligt mere nuanceret, men de har ikke rigtig fået indflydelse på litteraturstudiet. Selv tværkulturelle formstudier af byer er også svagt repræsenteret i studiet af by og litteratur (f.eks. Kostof, The City Shaped; Kostof, The City Assembled).

4) Individuel byerfaring: Endvidere er perspektivet på byerfaringen det individuelt perciperende bymenneske og dets oplevelse af bl.a. sansechok, mangel på overblik, anonymisering, opløsning af stabil omverdensorientering og af de traditionsbånd der før holdt den enkelte fast i en differentieret kollektiv sammenhæng. Modsætning er her ikke en anden identitet, men massemenneskets ikke-identitet, eventuelt rollemenneskets forvirring i en kultur af permanente rolle- og positions- 
skift (Larsen, “... et åndepust på spejlglas”). Flanøren som prototype kender vi, ja genkender vi, næsten med automatpilotens pavlov-refleks (Larsen, "Døgnets flaner").

\section{Netverker}

Hvad er der nu i vejen med den måde at gå til byen på, om jeg så må sige; den har jo virket godt i mange år? Men den stemmer ikke med de mere fundamentale træk ved byformationer som byhistorikere fremhæver på tværs af bykulturer på forskellige kontinenter: Byer kan slet ikke betragtes som individuelle steder, selv ikke individuelle steder med dynamiske og ekspansive ændringer. Grundlæggende i byhistorien er at byen aldrig opstår alene og fungerer alene, men altid i netværk. Byers fundamentale natur er at opstå og fungere i netværk og ændre status når netværket, ikke byen i sig selv som individuelt udtryk for en generaliseret by, svækkes, forskydes eller helt går under. Det er vel at mærke ikke de sidste dages hellige blandt byhistorikere jeg tænker på, men ideer der allerede har været til rådighed i en række år, men blot ikke er blevet brugt, akkurat som tilfældet var med bl.a. Simmel da han kom på dagsordenen i i96o'erne.

Netværksdannelse er den grundlæggende pointe i Paul M. Hohenberg og Lynn Hollen Lees' The Making of Urban Europe I000-I950 (1985) og i Georges Jehel og Philippe Racinets La ville médiévale. De l'Occident chrétien à l'Orient musulman (Ve-XVe siécle) (I996). Netop fordi byer indgår i netværk, sker byudvikling i ryk der altid involverer alle byerne i netværket, om end i forskellig grad og med forskellig styrke - norditalienske handelsbyer og hansestæderne i middelalderen opstod som de første stærke netværk efter Romerrigets netværk gik i opløsning, men med genbrug af en del af dets veje, befæstninger og bygninger og andre urbane installationer. "Byen er ikke en autonom enhed", siger et par byhistorikere (Jehel og Racinet 6I), og endnu tydeligere er en kapiteloverskrift hos Hohenberg og Lees: "Systems of Early Cities”, der følges op af teksten, bl.a.:

"Byer inden for deres mure har indtil nu tiltrukket sig den meste af vores opmærksomhed, men hvad med deres vigtige forbindelseslinjer udadtil? Middelalderbyerne var korsveje lige så meget som de var adskilte fællesskaber. Faktisk eksisterede de først og fremmest på grund af og med henblik på udveksling." (Hohenberg og Lees 47)

Dette synspunkt lader sig uden videre overføre på amerikanske forhold, da dette kontinents byer blev dannet som del af et kolonialt netværk. Måske kunne denne indsigt forny den europæiske byforståelse baglæns, således som de forannævnte lægger op til, i stedet for at projektionen går den anden vej over Atlanten. For det første gør Charles Glaab og A. Theodore Brown i A History of Urban America (1983) opmærksom på at de amerikanske byer ikke opstod, fordi landbruget bredte sig og gradvis fik brug for en by bagefter på forskellige steder i en repetition af de grund- 
læggelsesforestillinger der ofte har præget europæisk historie om de "første byer". Mange amerikanske byer var der før lokal agrar virksomhed:

“... selve bevægelsen vestover var muliggjort af urbane impulser. [...] Fra begyndelsen var økonomisk udvikling bestemt af byerne, bundet til handel og kommunikationsnetværk som stimulerede et urbant perspektiv, både for folk i byen og på landet. [...] Pittsburgh, St. Louis, Louisville og Cincinnati blev alle grundlagt før der var noget betydningsfuldt landbrug i deres områder." (Glaab og Brown 29)

Bemærkningen: "Amerikansk byhistorie begynder med den lille by - fem landsbyer hugget ud af vildnisset" (Callow 36) antyder at byer altid kommer i klumper. De indgår derfor i flere sammenflettede netværk, for de største byer koloniale netværk i stedet for lokale:

"Der eksisterede fem vigtige urbane centre i kolonierne i det tidlige I8. århundrede der hver dominerede en kystregion. De understøttede ikke et detaljeret netværk af mindre steder, men tenderede til at opsuge al urban virksomhed. [...] På eller nær kysten havde Boston, Newport, New York, Philadelphia og Charleston ofte tættere forbindelse til London end til hinanden. Hver knyttede deres agrare bagland til købmænd eller markeder i London frem for at skabe et enkelt amerikansk netværk." (Monkkonen 43)

Eric Monkkonen argumenterer her på samme måde som Hohenberg og Lees (59ff) gør for europæisk middelalder. Selvfølgelig er det ikke forkert, peger de på, at karakterisere en by ud fra en "central pladsteori" - den store by er centrum for et opland. Men man fanger ikke dermed hvad der gør den til en by og ikke bare et magtcentrum. Her skal man se ud over denne lokale magtstruktur og finde det eller de netværk der bestemmer dens særlige bykarakter - dens "netværkssystem". I dette tilfælde altså tage London med.

Det er altså muligt at se på byhistorien, i og uden for Europa, uden at have sit faste udgangspunkt i den centrerede europæiske middelalderby og dens opløsning. Denne opløsning stammer ikke kun fra byens kaotiske ekspansion. Men - hvis der er tale om en opløsning - den stammer fra omrokeringer af netværkets positioner og karakteriserer derfor den ekspanderende by lige så meget som de byer der i samme bevægelse ikke kommer til at ekspandere, men dog er del af samme netværkssystem. Med dette blik på byhistorien bliver netværket centralt og skaber dermed en direkte forbindelse til de teorier om det samfund der under forskellige navne er foldet ud af, eller ved at folde sig ud af, modernitetens urbane samfund. Manuel Castells har kaldt det netværkssamfundet (se indledning til Castells) og er stadig den skarpeste tænker af dette begreb. Knudepunkterne i disse netværk er knudepunkter for de globale bevægelser eller strømme der følger eller er bestemt af de digitale eller digitalt styrede kommunikations- og transportkanaler. Byerne er dele af disse netværk, men ser i modsætning til modernismens billede af byen ikke sig selv som styrende. De oprindelige netværk var stabile over meget lange perioder 
på trods af interne positionsskift blandt de involverede byer, mens de nye netværk er mobile.

Det er en omfattende og kompleks historie, som jeg ikke kan overskue i detaljer. Men hvis vi kan bruge netværket som grundbegreb, vil det kunne opfylde mit ønske om dobbeltorientering af byopfattelsen - både forud for og efter modernitetens by og dens modernistiske fortolkninger - og mit ønske om et transeuropæisk grundlag. Som den første opgave for et fremadrettet syn på byen i forhold til et fornyet studium af forholdet mellem litteratur og by ligger der for mig at se en opgave i et se hvorledes disse to typer netværksovervejelser hænger sammen og skaber et andet syn både på byhistorien og på byens rolle i verden i dag hinsides modernitetens byopfattelse. Byen er allerede blev brugt som en generativ metafor for de digitale netværk, som omvendt bliver brugt som model for at forstå netværkssamfundet (Larsen, Mutters alene; kap. 4). Disse netværksopfattelser er ikke nye - som man kan se af udgivelsesårene på mine referencer. Men der er ikke draget konsekvenser af dem i studiet af by og litteratur.

Den anden opgave bliver at finde ud af om og hvordan sådanne synspunkter kan bliver relevante for litteraturanalysen og litteraturhistorien, altså ikke bare mulige, men relevante. De elementer i byrummet, også modernitetens, der kommer til at tiltrække sig opmærksomhed i litteraturanalysen vil derfor mindre blive oplevelsen af byens interne spændinger mellem orden og kaos, inde og ude, by og natur, individ og masse osv. eller dens karakter som ikke-sted. Den er et sted, nemlig i et netværk. Hovedsagen bliver alle de elementer i byrummet og menneskelige relationer der peger ud over dette rum: veje og gader, kabler, massekommunikationsnetværk, telegrafer, telefoner, skinner og lufthavne, rejser og migrationer osv.alt det på et bestemt sted der gør det til et netværksknudepunkt og peger udad (Anderson; Çelik; Larsen og Petersen; Larsen, "Gadens rum”; Larsen, Tekster uden grcenser; kap. I2 og I3). Behovet er ellers klart: Mange litteraturanalyser påstår at byerfaringen er generel, også der hvor gadetrafikken ikke er direkte synlig. Alligevel kan langt de fleste ikke undvære direkte referencer til det fysiske byrum og til eksplicitte urbanerfaringer i teksterne for at drøfte byen som generaliseret og litterært relevant erfaringsrum (Larsen, "Lyrikken”).

Én konsekvens af netværkstankegangen er at det ikke er individets konfrontation med byens sansebombardement eller forvirrende labyrinter der tiltrækker sig mest opmærksomhed. Det er oplevelsen af gennem byen at være forbundet med en større verden på mange niveauer, at få mulighed for eller blive udelukket fra at deltage i de strømme - ofte kaldt flows (Castells; Appadurai) - den giver mulighed for i og gennem de netværk byen åbner for. Farligt, lovende, udfordrende - men uundgåeligt $\mathrm{i}$ dagens netværkssamfund. I moderniteten lever man $i$ byen på godt og ondt. I dag lever man med byen på godt og ondt. Hvordan fremstiller eller bruger litteraturen den omstændighed? Der er også en tredje opgave. Den vender jeg tilbage til når jeg har læst et par tekster. 


\title{
At leve i byen
}

Balladen om dem der blev $i$ byen hedder et langt digt fra Jess Ørnsbos debutsamling Digte (1960). Det efterlader ingen tvivl om hvordan det er at leve $i$ byen når man ikke kan slippe væk fra den, selvom man gerne ville eller måske burde af hensyn til personlighed, identitet og integritet. Omkring 1960 kom modernismen til Danmark i den internationale betydning af ordet, med alle de formeksperimenter og temaer som den europæiske tidlige modernisme og højmodernisme dyrkede. Herunder den tvetydige fascination af byen i Ørnsbos karakteristiske grotesk-idiosynkratiske stil (32):

\author{
"Men os inde fra byen \\ udhulede af rør og ledninger \\ os der brækker os \\ os der skriger i pissoirerne \\ os med sørgmodige negle \\ os med hoveder sønderslåede i kældre [...]"
}

By er overalt, inde og ude. Den går i kroppen, den krop der undertrykkes og fremmedgøres af byens inhumane automatik som når folk hænger "i alt for små stropper/ som pølser i en skorsten” (3I). I digtets groteske billedsprog er byen først og fremmest fragmenterede og fragmenterende kropsregistreringer, så voldsomme at de aldrig samles til overblik og helhed, hverken $i$ forhold til personen selv eller verden omkring ham eller hende.

Ballade skal ikke her forstås som middelalderballader: danseviser med formelagtig opbygning og omkvæd uden mange krops- og omverdensdetaljer men med klare episke linjer. Det er snarere i Bertolt Brechts forstand: enkle, folkelige former med kritik af magtforhold i mennesker, mellem mennesker og i den sociale omverden. Enkelheden er kompleks på det sproglige plan, som man kan se af citatet ovenfor. Men handlingsgangen er enkel. Det er en søndag fra morgen til aften og natten med. Et helt døgn skildret i frådende kropsregistreringer på en måde så man ved at det gentages dag efter dag, weekend efter weekend.

Digtet begynder $\mathrm{i}$ toget med passagerpølserne i stropperne og flokdyrene i toget: "Med et sidste ryk/ falder flokken sammen/ mod den sidste i rækken/ en fedtet kogebog/ der klapper i” (3I). Og det slutter når de forlader toget i en identifikation med den brugte og nu ubrugelige S-togsbillet: "Langt nede ser jeg dem/ aflevere billetten/ og resten af deres person" (37). Her er det livet der er formelagtigt og serialiseret, ikke sproget som i middelalderballaderne. Den robotiserede krop mindes kun kropsligt om drifter på afstand og i metaforiske fordrejninger, som når pigen ser "mændenes skaldede hoveder/ ovenfra/ som en vældig erektion" (35). Kropsligt nærvær er voldeligt, ulækkert og smertefuldt: "natten er fuld af snegle/ og pludselige skrig/ blodet breder sig mere og mere" (37).

Alt foregår som en klaustrofobisk gentaget cirkelbevægelse i et rum uden ud- 
gang. Sporvognen kører "uvist hvorhen” (35), og man "tager i skoven/for at få fred/ tager søndagen for sig selv/ og genner den ind ad en skovvej” (33). Parken, det alternative interne byrum, er ikke bedre: "Selv parkernes skønhed besværes:/ parkerne/ korthårede veldresserede plæner/ [...]/ en kort undskyldning/ så sidde/ og ikke komme hinanden ved" (34). Det eneste naturen kan bruges til, er at levere fremmedgjorte billeder af en alternativ verdens umulighed og utilgængelighed: "dybt nede i mørket/ bevæger vi os sidelæns/ som krabber i havets krampe” (37).

Ørnsbo gennemspiller i tilspidset form, fræsende som bytrafikken, modernismens tvetydige holdning til byen, her mere frastødende end mulighedsrig. Selvom digtets episke forløb knytter sig til døgnet set som en togtur, er det ikke en tur der fører ud af byen, men understreger hvor futilt det er at bevæge sig væk. Toget har ingen exit-skilte. Men stadigvæk så voldsom en udfordring at det kalder på alle sprogets og erfaringens registre, akkurat som hos Kingo: Han skriver bedst om det jordeliv han forkaster. Byen er en poetisk generator af dimensioner, simpelthen fordi man ikke kan slippe for at være i den og skal overbyde og overvinde den $\mathrm{i}$ sproget. Derfor har digtet stadig både saft og kraft.

Alle modernismens temaer gennemspilles: identitetsproblem mellem individualitet og masseliv, den sanselige adgang til verden uden sammenhængende overblik, vægten på at rummet tilegnes i bevægelse, om end den går i ring, byens allestedsnærvær der næsten gør den til skæbne og rummets dikotomisering mellem indre og ydre i forhold til byen og i forhold til mennesket - den første som en modsætning mellem by og natur, den sidste som en modsætning mellem krop og bevidsthed. Ørnsbos digt er én af mange tekster der skaber et billede af byen som dækker forståelsen af byen og byerfaringen i modernitetens samfund når litteraturhistorien skal skrives. At teksten dermed dateres, siger sig selv, men ikke at den dermed bliver kopivare. Den tilhører blot som alle tekster et historisk paradigme.

\section{At leve med byen}

Ørnsbo lever i byen fordi han ikke kan andet og har det ad $\mathrm{H}$ til, når han ikke lige skal have sproget til at flamme op. For det får byen det jo til. I Amitav Ghoshs roman In an Antique Land (I992) ser det helt anderledes ud. Ikke bare samler han i romanen hele byhistorien op: middelalderby, samtidens lille by i opløsning under den store verdens tryk og samtidens storbyer. Men den handler ikke om byerne der er ingen beskrivelser der karakteriserer dem som store eller små, skræmmende eller lokkende, beskyttende eller truende. De er ikke i sig selv interessante som erfaringsrum, men eksisterer bare som knudepunkter for det romanen virkelig handler om - relationer mellem mennesker og kulturer på lokale steder, men på translokale betingelser. Det er de relationer byerne repræsenterer, understøtter og udvikler gennem deres indbyrdes relationer. Deres eget særlige rum eller æstetik er ikke interessante. De er punkter i et netværk med skiftende betydning, alt efter de relationer de skaber. 
Hovedpersonen, Amitab, er en ung indisk antropolog fra Mangalore på Indiens vestkyst. Han skal skrive en afhandling baseret på nogle gamle manuskripter der delvis findes i Cairo, men som også har aflæggere i Tyskland og USA. I hvert fald er studiet af dem ikke lokaliseret på det sted de omhandler. Dokumenterne handler om to middelalderkøbmænd og deres handelsruter mellem Aden, Cairo og Mangalore. Den ene er jøde, den anden arabisk muslim. Netop fordi de ikke er bundet til samme dikotomisk opbyggede byrum bag mure og volde, men til at det trekantede urbane netværk fungerer friktionsløst, er deres forskellige etniske og religiøse baggrund en stor gevinst for dem. Det giver dem adgang til mange flere kontakter, sprogsamfund og oplysninger som får deres forretning til at blomstre. Det er disse bevægelser der skildres, ikke det gamle Cairo. "De var altid hurtige til at sende nyhederne videre til deres venner, hvor de end befandt sig, og de har helt sikkert holdt sig underrettet i god tid før farlige begivenheder i Syrien og Palæstina” (Ghosh I6).

For at kunne studere dokumenterne slår hinduen Amitab sig ned i en lille landsby nær Cairo, altså et muslimsk samfund. Ung er han, og hverken erfaren eller berejst selvom han lige for en ordens skyld har orienteret sig om lokal skik og brug. De lokale, både voksne og jævnaldrende unge, er endnu mindre orienteret om den store verdens andre mennesker, steder og ideer. De er mest optaget af slægtsbindinger, muslimsk rettroenhed og konkurrencen med nabolandsbyen. Her er vi som $i$ en europæisk middelalderby, udleveret til hinanden og de konflikter og fejlfortolkninger det giver. Ghosh skildrer humoristisk hvordan alle taler forbi hinanden, men alligevel finder sammen.

Men byen kan ikke leve på den måde, lige så lidt som den lukkede europæiske by. Vi er i optakten til Golfkrigen omkring I990, og ekkoet af en endnu større konkurrence end den med nabobyen står klar da Amitab og den lokale mullah skændes. De sammenligner nu både Ægypten og Indien med Vesten og hævder begge at de udmærker sig ved at være mere lig Vesten end den anden part, især med henblik på våbenarsenaler. Samtidig fornyes landsbyen gradvis med ny teknologi, især kommunikativ teknologi, og den store verden bliver endnu mere nærværende. Det er moderniteten der sætter sig igennem, men i former der hører til den koloniale periferi og ikke svarer til billederne af den forandrede middelalderby, selvom det er et par lukkede landsbyer der tvangsåbnes, blot i anden position end de europæiskvestlige regioners egne byer. Den udvikling kulminerer da de unge mænd i Amitabs omgangskreds enten indkaldes til hæren eller drager som gæstearbejdere til andre steder for at kunne leve, bl.a. til Bagdad. Den afgrænsede by opløses ikke fordi den breder sig, men fordi den med eller uden beboernes viden og medvirken viser sin afhængighed af de netværk den lokale verden er del af, forholdet til Vesten i det store perspektiv, besøget af Amitab fra Mangalore i det lille og personlige.

Amitab tager nu videre til New York for at studere og lover at komme tilbage og overhovedet at holde forbindelsen ved lige, bevare netværket intakt. Da han returnerer til landsbyen, er kammeraterne væk - i hæren eller i Bagdad, og han filosoferer med en af de ældre, uden at gøre sig klart at han er dårligere underrettet end de 
to middelalderkøbmænd han studerer, og at han selv er én af dem der foretager den rejse han her undrer sig over:

“'Ved du hvorfor de rejste?' spurgte jeg. 'Var der en særlig grund?' - Shaikh Musa trak på skuldrene. 'Hvorfor rejser nogen overhovedet væk?' sagde han. 'Lejligheden viser sig, og den må man bruge.”' (Ghosh I52)

Det er det byen gør: viser en lejlighed til bevægelse. Det er den lejlighed man får når man lever med byen, og ikke er låst i den.

Den kan også bruges til andet end en fysisk rejse med netværksbyen som udgangspunkt: Amitab ringer fra New York til den ven, Nabeel, der er i Bagdad som gæstearbejder. Det løber ud i sandet med støj på linjen og Nabeels besvær med at kunne tage telefonen - et opkald fra USA i Saddam Husseins Bagdad øjeblikke før Golfkrigen begynder, mens arbejdsgiver og andre arbejdere hører på - det er ikke optimalt. Netværkets knudepunkter ændrer karakter gennem de magtrelationer der styrer det, og som sætter sig igennem i byen og opleves gennem byen.

Amitab hører aldrig noget til Nabeel mere. Han "forsvandt ud i historiens anonymitet" (Ghosh 353) lyder romanens sidste ord. I denne type by er den enestående identitet som varig konstruktion, også i eftermælet, ikke interessant, og det grundlæggende behov for kritisk selvrefleksion som en del af den permanente selvkritik, individuelt og kollektivt, står svagere end i modernismens tekster. Byen ødelægger ikke identitet gennem sansebombardementet, massegørelse eller klaustrofobi som hos Ørnsbo og i modernismen. Den giver plads en tid så vi kan leve med den og dermed få lejligheder til bevægelser - fysiske og andre - der kan bruges på tværs af etniske, kulturelle og religiøse skel. De er ikke ubegrænsede eller evige. De flytter sig når netværket skifter sine store og små urbane knudepunkter. Derfor skal de bruges når man møder dem.

\section{En borbar cestetik?}

Undersøgelsen af perspektiverne i netværksbegrebet for byhistorie og byerne i dag, hinsides modernitetens by, er den første opgave foran os, både med hensyn til byen før modernitetens gennemslag og de fremadrettede samtidige byer og byerfaringer. Ghosh og andre læsninger af modernismens tekster kan være inspirationer her. Men én svale eller et par stykker gør ingen litteraturhistorisk sommer. Der skal arbejdes et bredere litteraturhistorisk metaniveau frem, akkurat som det skete i I960'erne for byen i modernismen. Den anden opgave er at se på de relevante analytiske muligheder. Det har jeg kort skitseret ovenfor. Den tredje opgave er at undersøge hvilke æstetiske former der påkalder sig opmærksomhed på de betingelser.

Byens æstetiske kvaliteter knytter sig mindre til den massive sanselige fremtræden der appellerer til den enkelte i chok, forførelse eller hvilke reaktionsmønstre der nu har været tale om. Byens specielle æstetik og den vareæstetik der styrer dens materielle fremtræden som afgrænset rum er mindre interessant. Mest interessant 
er byen som sted for interaktion mellem mennesker og med alt det der ligger uden for byen men set gennem byen - dens translokale appel. Hvordan ser den æstetik ud? De lufthavne eller andre konstruktioner med mere eller mindre anonym globaliseret arkitektur? De mange kopier af arkitektoniske strømninger i relativt ensartede havnefronter og huse? De mange relativt ens designede ting i hverdagen, produceret på vilkårlige steder der blot følger den globale pengestrøm? - Alle disse ting har den karakter at vi kan overse dem eller selv fylde dem med de ændringer, særpræg og misbrug som vi oplever som væsentlige. En bærbar æstetik, så at sige. Måske kan litterære formninger af byerfaringen og den litteraturhistoriske behandling af dem give inspiration tilbage på byhistorie og på bysociologi. Men en ny tænkemåde kan næppe sættes i gang her, før en sådan gentænkning af forholdet mellem by og æstetik finder nogle klare udtryksformer, akkurat som det tidligere er sket i udviklingen af forståelsen af vareæstetik i forhold til modernitetens byer gennem modernismens formeksperimenter.

Genlæsninger af tekster inden for modernitetens horisont hører med. Allerede Jens Baggesen i I70o-tallets slutning fornemmede netværkets realitet. Ganske vist handler Labyrinthen (I792-I793) om en stribe enkeltbyer som han skildrer i næsten personaliserede portrætter så de får en adskilt identitet. Men når han er i dem, bliver han straks rastløs og oplever sig selv og omverdenen på beslægtet vis. Faktisk er det styrende urbane princip i hans rejseskildring det samlede netværk af byer han rejser imellem, og som han alle giver en bærbar æstetik, mere farvet af dens relationer til de andre byer, hvis særpræg bestemmes af hvordan Baggesen skildrer netop denne by - Magdeburg, Strassbourg osv. - som han nu giver sig i lag med (Larsen, "By og litteratur"). Han oplever først og fremmest et europæisk urbant netværk.

Senere spekulerer Mac i John Dos Passos' U.S.A.-trilogi (I939) over at ankomme til byen: "Den unge mand går hurtigt alene gennem mængden" (I, v). Han er grådig efter at indtage byen efter at have turet rundt i staterne. Til allersidst, små 2000 sider senere, har han ingenting fået og er på vej væk igen. Han hitchhiker og ser samtidig et fly højt oppe: "Højt i det blå over hans hoved summer et fly" (III, 559). Det følger vi så som en parallel bevægelse til langt, langt væk, inden vi vender tilbage til ham der står ved vejkanten, "hundrede mil nede ad vejen" (III, 56I). Byen er ikke som den klassiske by lover: Her tager man hen, fylder og overfylder sig. Heller ikke som modernitetens by: Her er nok af muligheder, vælg bare. Den er præget af parallelle bevægelser der hver bestemmer et netværk - parallelle historier og, som her, parallelle bevægelser i luften og på vejen, alle med byen som omdrejningspunkt. Men med Macs ambition om at komme til en anden by end den der faktisk findes, ser han dem ikke før han skal væk. Han benyttede ikke lejligheden, som Shaikh Musa ville sige. Det er den oversete idé om netværket vi møder, som den forpassede lejlighed når byen ses som noget andet end den er.

Jens Smærup Sørensens genbrug af hjemstavnsromanen i Mcrkedage (2007) er ikke særlig urban i modernistisk forstand. Det er landboslægternes og landsbysamfundets opløsning i landsbyen Staun, næsten som i I920’ernes og I930'ernes lit- 
teratur men med en drejning i komposition og persontegning der mere har med det tidlige 2I. århundrede at gøre. Bl.a. i to af de kvindelige hovedpersoner. Ellen vokser op som lam og polioramt og ser den stærke Peder med udlængsel og flyvercertifikat styrte ned og dø. Men hun overvinder sit handicap og får en international karriere gennem FN, især i Afrika. Mary rører sig derimod ikke ud af flækken. Men hun læser, hjulpet på vej af Ellen med udsynet. Og på den måde kigger hun ud i verden. Hun føler et fællesskab med dem der har forladt Staun: "For også hun selv har jo for længst lagt livet i Staun bag sig. Også for hende er den her by blevet et tilfældigt sted i verden. Selv om hun aldrig har været andre steder" (Sørensen 306). Hun lever ikke nødvendigvis $i$ Staun, men hun lever med den som et sted hvorfra verden kan ses. Og det har ikke noget med stedets størrelse at gøre, men med de netværk man placerer sig i med de midler man har: international karriere eller litteratur.

Det er netværkstankegangen hun formulerer på sin egen måde. Hvert sted er et tilfældigt sted i verden som man gør til sit ved at benytte lejligheden, igen med Shaikh Musas ord, til at gøre det til udgangspunkt for at bevæge sig ud i verden, fysisk, mentalt, digitalt eller på andre måder. Men alle er måder der forudsætter, bruger og flytter de netværk bevægelsen er afhængig af. Byens dæmoni er borte, dens betydning ikke. Med Baggesen, Dos Passos og Sørensen som lidt tilfældige eksempler kan man se at der er andre relevante træk gemt i tekster inden for hele modernitetens periode end dem man plejer at sætte gadelys på. Måske er modernitetens byrum en parentes mellem det gamle netværk og det nye urbane netværk - og måske ikke særlig interessant i det lange løb, medmindre vi kan se konturerne af noget andet i dem også, akkurat som vi i bagklogskaben ser tankegange og udtryksformer på spring hos Dante eller Shakespeare, hos Holberg eller Ewald, og gennem dem tager dem med os videre frem. 


\section{LITTERATURHENVISNINGER}

Anderson, Stanford. On Streets. Cambridge: MIT Press, 1986.

Appadurai, Arjun. Modernity at Large. Minneapolis: University of Minnesota Press, I996.

Baggesen, Jens. Labyrinthen. København: Gyldendal, I965.

Brand, Dana. The Spectator and the City in Nineteenth Century American Literature. Cambridge:

Cambridge University Press, I99I.

Callow, Alexander B. American Urban History. An Interpretive Reader with Commentaries (3rd ed.). New York: Oxford University Press, I982.

Castells, Manuel. The Network Society. A Cross-Cultural Perspective. Cheltenham: Edward Elgar, 2004.

Çelik, Zeynep, Diane Favro og Richard Ingersoll. Streets. Critical Perspectives on Urban Space. Berkeley:

University of California Press, I994.

Dos Passos, John. U.S.A. I-III. New York: The Modern Library, I939.

Ghosh, Amitav. In an Antique Land. New Delhi: Ravi Dayal Press, 2000.

Glaab, Charles og A. Theodore Brown. A History of Urban America (3rd ed.). New York: Macmillan, I983. Hohenberg, Paul M. og Lynn Hollen Lees. The Making of Urban Europe 1000-1950. Cambridge: Harvard University Press, 1985 .

Jehel, Georges og Philippe Racinet. La ville médiévale. De l'Occident chrétien à l'Orient musulman (Ve-XVe siécle). Paris: Colin, 1996.

Johnston, John H. The Poet and the City. Athen: University of Georgia Press, I984.

Kostof, Spiro. The City Shaped. Boston: Bulfinch, I99I.

Kostof, Spiro. The City Assembled. London: Thames and Hudson, I992.

Krakauer, Siegfried. Die Ornament der Masse. Frankfurt a.M.: Suhrkamp, I98I.

Larsen, Svend Erik. "By og litteratur. Rundt i landsbyrinten. Bidrag I9/20 (I985): I05-I56.

Larsen, Svend Erik. "Lyrikken - skyklap eller brændglas.” Krystalgitteret. Den lyriske genres funktion.

Red. Annelise Ballegaard Petersen og Carsten Nicolaisen. Odense: Odense Universitetsforlag, I988. 39-66.

Larsen, Svend Erik. “'... et åndepust på spejlglas'. Om krop, identitet, fantasi og masse.” Fantasi og fiktion. Red. Erik Svejgaard og John Thobo-Carlsen. Odense: Odense Universitetsforlag, I989.

27I-3I2.

Larsen, Svend Erik. “Døgnets flaner. Flanøren som stereotype.” Stereotyper i Europa. Red. Gunhild Agger, Barbara Gentikow og Ulf Hedetoft. Århus: Aarhus Universitetsforlag, I990. 2I9-235.

Larsen, Svend Erik. “Gadens rum - byens grænse.” Granser. Red. Frederik Stjernfelt og Anders Troelsen. Århus: Aarhus Universitetsforlag, I992. IO4-I32.

Larsen, Svend Erik. I byen med Balzac. Odense: Syddansk Universitetsforlag, 2002.

Larsen, Svend Erik. Mutters alene. Ensombed som littercert tema. København: Gads forlag, 2002.

Larsen, Svend Erik. Tekster uden granser. Litteratur og globalisering. Århus: Aarhus Universitetsforlag, 2007.

Larsen, Svend Erik. "'Fra kvalmfulde Mure! Til Marken saa huld!' Romantikerne og byen.” Romantikkens Verden. Red. Ole Høiris og Thomas Ledet. Århus: Aarhus Universitetsforlag, 2008. $49-66$ 
Larsen, Svend Erik og Annelise Ballegaard Petersen. La rue - espace ouvert. Odense: Odense Universitetsforlag, 1997 .

London und Paris (fra I8II: London, Wien und Paris). Halle/Rudolstadt, I798-I8I5.

Monkkonen, Eric H. America Becomes Urban. Berkeley: University of California Press, I988.

Mumford, Lewis. The City in History. Harmondsworth: Penguin, 1979.

Short, James. The Social Fabric of the Metropolis. Contributions of the Chicago School of Sociology. Chicago: Chicago University Press, I97I.

Simmel, Georg. "Die Großstädte und das Geistesleben.” Das Individuum und die Freiheit. Berlin: Wagenbach, I984. I30-I39.

Sørensen, Jens Smærup. Markedage. København: Gyldendal, 2007.

Weber, Max. Die Stadt. Tübingen: Mohr Siebeck, 2000.

Wordsworth, William. The Prelude. London: Norton, 1979.

Ørnsbo, Jess. "Balladen om dem der blev i byen.” Udvalgte digte fra tresserne. København: Gyldendals bogklub, I970. 3I-37. 